Received : 2019-06-23 Revised : 2019-06-26 Acceptance : 2019-06-27 Publish : 2019-07-22

\title{
The Relation Between Anxiety and Nurses' Performance at Atma Husada Mahakam Hospital, Samarinda
}

\author{
Mukhripah Damaiyanti ${ }^{1}$ \\ ${ }^{1,2}$ Department of Nursing, Faculty of Health and Pharmacy, Universitas Muhammadiyah \\ Kalimantan Timur \\ Corresponding Author : $\underline{\text { md356@umkt.ac.id }}$
}

\begin{abstract}
Nurses working at the Mental Hospital are different from other section nurses, there are loads of nurses possessed anxieties when they treat mental patients and it disrupts their performance. Whereas, the nurse performance has a vital and strategic value that depicts the quality of service in the hospital. Baring that in mind, this study aims to determine the relationship of anxiety of nurses toward their performances of treating patients at Atma Husada Mahakam Mental Hospital, Samarinda. Using the Lameshow formula, this study obtains a sample size of 96 people. The sampling technique used is Stratified Random Sampling. This study data retrieval is in September - October 2017. The questionnaire used is The Six Dimension Scale of Nursing Performance (SDNS and Hamilton Anxiety Rating Scale (HAM-A). Bivariate analysis conducted uses the Pearson Product Moment with a p-value of 0,000 with the correlation value of anxiety on nurse performance in the frequency of nurses 'activities $r=0.41$ and the quality of nurses' activities $r=0.54$ which means that it correlates strongly. There must be some effort to minimize anxiety mental nurses by using a new innovation and training to increase nurses knowledge, abilities and skills so it can improve performance of nurses in carrying out nursing care and action.
\end{abstract}

Keywords : anciety, nurse performance,psychiatric hospital

\section{INTRODUCTION}

Anxiety is a psychiatric condition that is often found in the practice of psychiatry throughout the world. In general, People with anxiety possess one of either the awareness of physiological sensations or the awareness of nervous or afraid. The National Comorbidity Study report describes the prevalence of anxiety is $17.7 \%$ in 12 months. It is also known that the prevalence of lifetime anxiety in women is $30.5 \%$, and men $19.2 \%$. Anxiety is complex and mysterious medical disorders with about two-thirds of its patient are women, both in the clinical sample and in epidemiological study ${ }^{1}$.

Anxiety can form as a subjective feeling of anxiety, looking worried and agitated behavior, or physiological responses that originate in the brain and are reflected in the form of an increased heart rate and tense muscles. Signs of overall anxiety disorder are muscle tension, mental agitation, prone to fatigue, irritability, and sleep disorders. Anxiety is a threat of which the source is unknown, internal, vague and conflicted. Anxiety can be triggered by several factors including pathophysiological and situational ${ }^{2}$. The identification of Anxiety divides to four levels: mild, moderate, severe and panic. Each individual has a different level of anxiety this is marked by differences in the integrity and level of existing circumstances. The higher the level of 
individual anxiety the more physical and psychological conditions affects the patient. Anxiety is a part of everyday human life. For people who adjust well, anxiety can be quickly overcome. For those whose the adjustments are not good enough, anxiety can be the biggest threat of their lives and inhibit their daily activities ${ }^{3}$.

On the other hand, hospitals are complex organizations providing services to patients seven days a week, 24 hours / day. Doctors and nurses are the vital resources who spend most of their time in the hospital. They must do routine work overnight, in the often emergencies, with extensive workloads and stress can negatively affect their performance and quality of work life ${ }^{4}$.

Moreover, every step and detailed patient treatment activity must be recorded by the nurse as the evidence of work and the development of the patient's condition. The performance of nurses as health workers in hospitals provides constant and continuous service 24 hours to patients every day ${ }^{5}$. Nurses have a very important role in understanding and meeting patient needs. The performance of nurses in providing nursing care cannot be separated from all integral part and interaction aspects between nurses and patients ${ }^{6}$.

Thus, Nurses who work at the Mental Hospital are different from other section nurses. The level of work and knowledge of nurses is more complex than ordinary hospital nurse ${ }^{7}$. Not only are they responsible for patients with physical disorders but also they need to prioritize mental disorder patients of which the patients with mental disorders experience psychiatric function disorders often causing the obstacles in carrying out social roles in the family environment and surrounding communities ${ }^{8,9}$.

Most mental disorders sufferers are in DKI Jakarta Province with a prevalence of 20.3\%, followed by Nangroe Aceh Darussalam with a prevalence of $18.5 \%$, and East Kalimantan by $1.3 \%{ }^{10}$. Then, in the prevalence of disorders with the highest severe mental illness were in DI Yogyakarta and Aceh (2.7\%), South Sulawesi 2.6\%, and East Kalimantan had experienced an increase of prevalence of severe mental disorders by 1.4\%. The 2013 Basic Health Research Data records the prevalence of severe mental disorders in Indonesia reaching 1.7 per mile meaning that 1-2 people out of 1,000 Indonesians experience severe mental illness ${ }^{11}$.

The standard for the number of health workers with a population of 1:30 thousand people or 0.03 per 100,000 populations and the number of psychiatric nurses in 2015 was 6,500 people ( 2 per 100,000 populations). In other words, the number of mental health professionals in Indonesia has not been able to meet the minimum quota $\operatorname{set}^{12}$.

As mental nurses are required to have competence in nursing care and therapeutic communication activities. The nursing process for clients with mental health problems is a unique challenge for mental nurses because mental health problems cannot be seen directly as in physical health problems. The nurse's ability to play a role in solving mental patient problems also varies. Standard competence in mental nurses is not a few nurses who experience anxiety in 
Received : 2019-06-23 Revised : 2019-06-26 Acceptance : 2019-06-27 Publish : 2019-07-22

treating mental patients and interfere with nurse performance. Anxiety is generally expected to have a negative effect on performance. One consistent finding shows that people who have high levels of anxiety perform less well than those who have low anxiety on evaluative or egothreatening tasks ${ }^{13}$.

Nurse performance has a vital and strategic value; care provided by nurses is a core business and can make a major contribution to health services in hospitals. The quality of performance shown by nurses in providing care is a reflection of the quality of service in the hospital ${ }^{14}$. The importance of performance appraisal is concerned with determining the level of individual contribution or performance expressed in completing the tasks for which it is responsible.

Based on this phenomenon, researchers are interested in conducting research on the relationship of anxiety levels with the performance of nurses at Atma Husada Mahakam Mental Hospital in Samarinda.

Research purposes to identify anxiety levels of psychiatric hospital nurses ,to identify the performance of nurses in mental hospitals, to analyze the relationship between anxiety levels and nurses' performance at the Mental Hospital

\section{RESEARCH METHODS}

This type of research is a correlational descriptive study with a cross-sectional approach. The population in this study is functional nurses at the RS of Atma Husada Mahakam Samarinda, amounting 132 people. This population then is filtered using the Lameshow formula resulted the number of samples is 96. The sampling technique used is Stratified Random Sampling. Retrieval of data is in September - October 2017 at the Atma Husada Mahakam Mental Hospital Samarinda.

The nurse performance questionnaire used in this research is The Six Dimension Scale of Nursing Performance (SDNS) consisting of 52 questions with 6 main sets: 1) leadership; 2) intensive / critical care 3) teaching / collaboration 4) planning / evaluation; 5) interpersonal relationships / communication within the team; and 6) professional development. This Research is divided into two stages. The first stage is the performance analysis of individual care activities in the workplace of nurses uses a Likert scale: 1 = performance while on duty is not anticipated, and $4=$ done most often. The second stage is the assessment of the quality of the tasks performed. With a Likert scale of $1=$ activities have been carried out unsatisfactorily until $4=$ perform very well. This instrument has a high level of ignorance with Cronbach alpha 0.97.

Anxiety questionnaire used is the Hamilton Anxiety Rating Scale (HAM-A). it is used due to it precision to measure anxiety. The questionnaire consists of 14 questions and the answer uses a Likert scale where $0=$ none (no symptoms at all, $1=$ mild (one symptom of the available 
Received : 2019-06-23 Revised : 2019-06-26 Acceptance : 2019-06-27 Publish : 2019-07-22

choices), 2 moderate (half of the symptoms present, 3 = severe (more than half the symptoms) existing, and $4=$ very severe (all symptoms that exist with a range of score 0-56 with a division of anxiety degrees score less than $14=$ no anxiety; score $14-20=$ mild anxiety; score $21-27=$ moderate anxiety; score $28-41=$ severe anxiety and score $42-56=$ panic. By using the Cronbach's Alpha score of 0.793 , this questionnaire is proven reliable.

Data normality test in this research is Kolmogorov Smirnov that useful to measure normal distribution data with a result of $p>0.05$. Data analysis with frequency statistics is important to determine demographic data. On the other hand, descriptive statistics is needed to determine the size of central tendency, standard deviation, range, and variance of data collected. The correlation of anxiety with nurse performance between the subset of frequencies of nursing activities and the quality of nursing activities from The Six Dimension Scale of Nursing Performance (SDNS) is determined using the Pearson Product Moment (r) test with significance at the 0.05 level.

\section{RESULT}

1. Univariate Analysis

a. Characteristics of Respondents

Tabel 1.1 Characteristics of Respondents

\begin{tabular}{lcc}
\hline \multicolumn{1}{c}{ Characteristics } & Frequency & Percentage \\
\hline Sex & 32 & 33.3 \\
$\quad$ Male & 64 & 66.6 \\
Female & & \\
Age & 50 & 52.1 \\
$\quad 20-40$ Y.O & 46 & 47.9 \\
$41-60$ Y.O & & \\
& 84 & 89.6 \\
Religion & 3 & 3.2 \\
$\quad$ Moslem & & \\
Christian & & 2.1 \\
& 2 & 89.6 \\
Educational Level & 86 & 8.3 \\
$\quad$ SPK & 8 & $\mathbf{1 0 0}$ \\
Diploma III & & \\
Nursing Bachelor + Ners & $\mathbf{9 6}$ & \\
TOTAL & & \\
\hline
\end{tabular}


Received : 2019-06-23 Revised : 2019-06-26 Acceptance : 2019-06-27 Publish : 2019-07-22

\section{Source: Primary Data}

Table 1.1 depicts the description of respondents by sex $66.6 \%$ is female, $33.3 \%$ male. The age range of 20-40 years as many as 50 people with the largest religion of Islam is the percentage of $89.6 \%$. The most education level are Diploma III Nursing graduates.

a. Anxiety

Tabel 1.2 Mean and The Standard Deviation for Nurse Anxiety

\begin{tabular}{lcc} 
& Mean & Standard Deviation \\
\cline { 2 - 3 } Anxiety & 26.4 & 9.7 \\
\hline
\end{tabular}

b. Nurse Performance

The data analysis of nurse performance are two separate data sets of 1) the frequency of activities carried out, and if carried out; and 2) the quality of the activities carried out.

Tabel 1.3 Mean dan The Standard Deviation of the frequency and quality of nurse activities

\begin{tabular}{lcc}
\hline \multicolumn{1}{c}{$\begin{array}{c}\text { Frequency of nurse } \\
\text { activities }\end{array}$} & Mean & Standard Deviation \\
\hline Leadership & 3.19 & .351 \\
Intensive Care & 3.59 & .227 \\
Teaching / Collaboration & 3.25 & .258 \\
Planning / Evaluation & 3.45 & .375 \\
Interpersonal Relations / & 3.77 & .208 \\
Communication & & Standard Deviation \\
\hline The quality / activities of & Mean & .864 \\
$\quad$ nurses & 2.82 & .986 \\
\hline Leadership & 2.87 & .901 \\
Intensive Care & 2.59 & .897 \\
Teaching / Collaboration & 2.79 & .208 \\
Planning / Evaluation & 3.15 & .891 \\
Interpersonal Relations / & 3.10 & \\
Communication & & \\
Professional Development & &
\end{tabular}

2. Bivariate Analysis 
Received : 2019-06-23 Revised : 2019-06-26 Acceptance : 2019-06-27 Publish : 2019-07-22

Table 2.1 shows Pearson Product Moment Test Relationship of Anxiety Level with Nurse

Performance between the subset of frequency of nursing activities and the quality of nursing activities

\begin{tabular}{clccc}
\hline \multirow{2}{*}{ Variable } & \multicolumn{4}{c}{ Nurse Performance } \\
\cline { 2 - 5 } & Frequency of nurse activities & Quality of nurse activities \\
\cline { 2 - 5 } Anxiety & $0.41 * *$ & $p$-value & $\mathrm{r}$ & $p$-value \\
\hline$* * \mathrm{p}=$ & significant value & $\alpha \leq 0.000$ & $0.53 * *$ & 0.000 \\
\hline
\end{tabular}

\section{DISCUSSION}

\section{Nurse Anxiety}

Based on the results of research conducted at Atma Husada Mahakam Hospital in Samarinda, the mean value is 26.4 , which describes the average nurse experiences moderate anxiety. This result is supported by a study entitled Anxiety levels related symptoms in personal nursing emergency in Greece explaining that mild anxiety levels occur in nurses with a result of $48.5 \%$.

The cause of anxiety possessed by nurses is because of the heavy workload. Wherever nurses perform nursing actions on acute mental patients, the characteristics of acute mental patients are attacking and threatening others (dramatic admission), the condition of patients who often protest against staff nurses commonly aiming of protest and refusal of treatment ${ }^{15}$.

This research envisages that the anxiety experienced by respondents in the form of anxiety, alertness and tension increases however nurses can still focus on taking care of patients with diligent therapeutic communication to patients (fostering relationships of trust). Mild anxiety is associated with tension in everyday life. This anxiety causes the individual to be alert and increase their perception. This anxiety can motivate learning and produce growth and creativity ${ }^{16}$.

Thus, the results of anxiety experienced by the respondent viewed from an emotional response shows nurses with mild disabilities seemed more relaxed but a little impatient, while those with moderate anxiety tended to be more impatient and irritable. Mild anxious emotional responses include feelings of relative comfort and security, calmness, automatic behavior, a little impatient, solitary activity, stimulated, calm. Anxious emotional responses include being alert, learning new skills, uncomfortable, easily offended, self-confidence faltering, impatient, and unhappy.

2. Nurse performance 
Received : 2019-06-23 Revised : 2019-06-26 Acceptance : 2019-06-27 Publish : 2019-07-22

Based on the results of data regarding the frequency of nursing activities obtained from The Six-D Scale, it shows all items performed by nurses at least sometimes during duty with an average score ranging from 3.17 - 3.77. On the contrary, the quality of nurses in performing nursing activities is satisfactory with an average score ranging from 2.59 - 3.15. Nurse performance is the activity of nurses in implementing the best authority, duties and responsibilities in order to achieve the objectives of the main tasks of the profession and the realization of the goals and objectives of organizational units ${ }^{17}$. Some researchers believe that nurses' performance will be better according to standards if nurses always improve their knowledge and skills. Nonetheless, lack of willingness or interest to learn becomes an obstacle in improving performance. Thus, one of the factors that influence someone's performance or one's productivity is work stress, so the rate of one's performance depends on how much stress is experienced. Therefore, work stress that occurs can cause accidents or health problems which in turn can cause decreased productivity and can also reduce a person's performance ${ }^{18}$.

The study result explains that a half of the respondents fall into the age category of 20-40 years as many as 50 people $(52.1 \%)$ of a total of 96 respondents. According this result indicates the correlation between the person age and the increasing quality of his performance. It is evidenced they performed the caring action more carefully and had a higher sense of responsibility in carrying out his duties ${ }^{19}$.

In addition, the majority of the sex of the respondents. There are 32 men $(33.3 \%)$ and 64 women (66.6). This is in line with the results of research that women are more flexible in carrying out nursing actions but most often faces stress in the workplace ${ }^{20}$. Previous researchers found that the greater number of men will lead to lack of confidence because they feel less suited to their work so that it will reduce concentration and morale. This opinion differs from the early history of the nursing profession, She worked in the name of love of a mother or woman ${ }^{21,22}$.

Moreover, the research results of the majority of respondents' education. The majority of educated diploma graduates were 86 people $(89.6 \%)$. The above results contradict the results of the study that one of the factors that can increase the productivity or performance of nurses is the formal education of nurses ${ }^{23,24}$. Not only education provides knowledge and the direct implementation of the task, but also the basis for self-development and the ability to use all the facilities, the higher education the higher work productivity ${ }^{25}$. Therefore, according to the previous researchers, there must to be a program to continue education to a higher level so that nurses have more knowledge and skills to improve performance.

\section{Relationship Anxiety with Nurse Performance}

Based on the results of data analysis conducted with the Pearson Product Moment test, it is obtained that $\mathrm{p}=0,000(\mathrm{p} \leq 0.01)$ so that $\mathrm{HO}$ is rejected. It means there is a relationship between anxiety on the performance of nurses in the frequency of nurse activities $r=0.41$ and the quality of nurses activities at Atma Husada Mahakam Hospital Samarinda with correlation coefficient $r$ 
$=0.54$. it is evidenced that it has a strong enough or large relationship between them. Anxiety experienced by nurses can functionally help improving work performance, vice versa. It is because performance depends on the level of anxiety experienced by nurses. If there is no

anxiety existed, there is no work challenge and it will affect the working performance ${ }^{26,27}$. They must be low due to the lack of effort to face the challenges. In line with the increase and anxiety, nurses work performance tends to increase because they are anxious to help nurses to exert all their abilities in meeting various requirements or job needs ${ }^{28}$. When anxiety has reached the optimal point that is reflected in the ability to carry out the daily work of nurses, increasing or increasing anxiety tends not to result in improved work performance ${ }^{29}$. Finally, when stress becomes too great, work performance begins to decline, because anxiety worries the implementation of work.

\section{CONCLUSION}

The anxiety of nurses at Atma Husada Mahakam Hospital in Samarinda can be considered a moderate anxiety. The measuring the frequency of performance of nurses shows the activities carried out by nurses when they are on duty. The quality of nurses in performing nursing activities is modest. However, mild to moderate anxiety will improve nurse performance due to at this level, it will stimulate nurses' motivation to learn to increase knowledge and abilities.

\section{SUGGESTION}

Anxiety can be minimize by increasing the self-confidence of nurses. We hope that by involving to some innovations and trainings, especially in the field of nursing, can increase nurses' knowledge, abilities and skills as well as its implementation of nursing care and actions. Satisfactory nurse performance can improve the quality of self (knowledge, skills, attitudes). In addition, it also can lift up their motivation to always find out new things and do what should be done as a nurse. As a result, it can also improve the quality of service or the performance of a professional nurse.

\section{ACKNOWLEDGEMENT}

To Universitas Muhammadiyah Kalimantan Timur for the funding of Penelitian Dosen Pemula in 2017.

\section{REFERENCES}

1. Sadock BJ, Sadock VA. Kaplan and Sadock's Comprehensive Textbook of psychiatry, 9th edition. Lipincott Williams \& Wilkins (2009).

2. Durand VM, Barlow DH. Essentials of Abnormal Psychology. Yogyakarta: Pustaka Pelajar (2007).

3. Kaplan HI, Sadocks BJ. Sinopsis Pskiatri jilid 2. Ciputat-Tangerang: Binarupa Aksara (2010). 
Received : 2019-06-23 Revised : 2019-06-26 Acceptance : 2019-06-27 Publish : 2019-07-22

4. Carpenito LJ. Buku Saku Diagnosis Keperawatan. Alih bahasa; Yasmin. Editor: Monica Ester. Jakarta: EGC (2000).

5. Stuart GW. Buku Saku Keperawatan Jiwa ed. 5. Jakarta: EGC (2006).

6. Bandra, Wayan I dan Prawitasari JE. Hubungan antara stress dan motivasi dengan kinerja dosen tetap pada Akper Sorong. Working Paper Series, 8 (2005).

7. Pratiwi MA. Peningkatan kualitas hidup kerja melalui analisa stress kerja serta faktor yang mempengaruhi. Jurnal Sains Pemasaran Indonesia, 8, 3 (2014).

8. Prihandhani IGAA S, Gandari NKM, Hubungan kompetensi, motivasi dan beban kerja perawat pelaksana dalam penerapan asuhan keperawatan dengan kinerja perwat diruang rawat inap Badan Rumah Sakit Tabanan. Jurnal Keperawatan BSI, 2, 1 (2019)

9. Purindra DS, Rosmaharani S, Nahariani P, Hubungan pemenuhan kebutuhan spritual dengan tingkat kecemasan pasien pra operasi, Jurnal Ilmiah Keperawatan, 3, 2 (2017).

10. Faiqoh E, Falah F, Hubungan antara sikap terhadap pasien penyakit jiwa dengan perilaku agresif perawat pasien jiwa, Proyeksi, 6, 1 (2019)

11. Riset Kesehatan Dasar (Riskesdas) 2013. Badan Penelitian dan Pengembangan Kesehatan. Jakarta, Kemenkes RI, (2013).

12. Yusuf AH, Fitryasari R, Nihayati HE, Tristina RD. Kompetensi Perawat dalam merawat pasien gangguan jiwa. Jurnal Ners, 11 (2016).

13. Vogel H, Collins, A. (2006). The relationship between test anxiety and academic performance. Journal of Abnormal and Social Psychology, 67 (2006).

14. Wazqar DH, Kerr M. Thesis. Graduate Program in Nursing, The University of Western Ontario (2015).

15. Ambar T, Sulistiyani, Rosidah, Manajemen Sumber Daya Manusia, Penerbit Graha Ilmu, Yogyakarta (2013)

16. Lwanga SK, Lemeshow S, Sample size determination in health studies: a practical manual, World Health Organization (1991)

17. Schwirian PM, Evaluating the performance of nurses: a multidimensional approach. Nurs Res, 27 (1978).

18. Szara M, Anna KD, Klukow J, Review of research tools for assessment of performance of nursing staff, Medical and Biological Science, 30 , 4 (2016).

19. Hamilton M, Hamilton Anxiety Ratting Scale (HAR-S). The Assesment of Anxiety states by rating. Jurnal Med Psychol, 32 (1959)

20. Kautsar F, Gustopo, D, Achmadi, Uji validitas dan reliabilitas Hamilton Anxiety rating Scale terhadap kecemasan dan produktivitas pekerja Visual Inspection PT. Widatra Bhakti, Seminar Nasional Teknologi (SENATEK), pp. 588-592 (2015).

21. Stathopoulou H, Karanikola MN, Panagiotopoupou F, Papathanassoglou ED, Anxiety levels and related symptoms in mergency nursing personnel in Greece, J Emerg Nurs, 37, 4 (2011)

22. Lutzen K, Ivarsson AB, Eriksson H, Salzmann M-Krikson, The core characteristics and nursing care activities in psychiatric intensive care units in Sweden, international Journal of Mental health Nursing, 17 (2008). 
Received : 2019-06-23 Revised : 2019-06-26 Acceptance : 2019-06-27 Publish : 2019-07-22

23. Videbeck, Sheila L, Buku Ajar Keperawatan Jiwa/Alih Bahasa, EGC, Jakarta (2008).

24. Haryono, S, DP3 salah satu indikator akuntabilitas internal unit kerja organisasi, Buletin Pengawasan No. 45 dan 46 Th. 2004, dikuti dari: http://www.pu.go.id/satminkal/itjen/buletin/4546dp3.htm

25. Zaini A, Stress kerja dengan kinerja Islam Rumah Sakit Aisiyah, JESTT, 2, 6 (2015).

26. Riandy, Pengaruh stress kerja terhadap kinerja karyawan pada PT. Borneo laboratorium Inspeksi dan Surveyor Service di Samarinda, eJournal Administrasi Bisnis, 4, 4 (2016).

27. Rahayu EA, washilah W, Haryono MH, Dwiprema LA, In Proceeding of The $9^{\text {th }}$ International Nursing Conference, Indonesia, pp. 490-496 (2018)

28. Kambuaya HG, Rompas S, Hamel RS, Hubungan tingkat pendidikan dan lamanya kerja dengan kinerja perawat di Rumah Sakit Umum Kabupaten Sorong, e-journal Keperawatan, 4, 1 (2016).

29. Handoko TH, Manajemen personalia dan sumber daya manusia, PT.BPFE, Yogyakarta, (2008). 